\title{
TRAGEDY AND THE SEDUCTIONS OF PHILOSOPHY
}

\author{
Miriam Leonard` \\ University College London, UK
}

Since antiquity, Greek tragedy has continually preoccupied philosophers. From Plato and Aristotle, to Hegel and Nietzsche, many of the most interesting ideas in the history of thought have been developed through a dialogue with tragedy. This article explores the continuities and ruptures between Plato and Aristotle's reading of tragedy and the so-called "philosophy of the tragic" which emerged in the late eighteenth century. The influence of this modern tradition has been so profound that, even today, no reading of Antigone, of Oedipus or of the Bacchae is not also, at least unconsciously, in dialogue with Hegel, with Freud and with Nietzsche. Although there is some recognition that the philosophical understanding of tragedy has historically shaped the discussion of ancient drama, classicists remain resistant to returning to its insights to further the study of classical texts. This article aims to redress the situation not only by revealing the persistent traces of the philosophy of the tragic in our modern critical vocabulary, but also by arguing that a renewed interest in this tradition will invigorate debates within our field. By looking at the examples of the French feminists Hélène Cixous' and Luce Irigaray's interpretations of Sophocles and Aeschylus, the article investigates the apparent tension between historicist and universalising readings of tragedy and argues that these two approaches are not necessarily incompatible.

Karl Marx's Eighteenth Brumaire opens with the much quoted statement: 'Hegel remarks somewhere that all great world-historical facts and personages occur, as it were, twice. He has forgotten to add: the first time as tragedy, the second time as farce'. ${ }^{\mathrm{I}}$ The identity of the 'somewhere' where Hegel is meant to have made this remark remains an open

\footnotetext{
* Email: m.leonard@ucl.ac.uk.
}

This article was presented at as a paper at Oxford and Cambridge and I am grateful to the audiences on both those occasions for their very helpful suggestions. In particular, I would like to thank Joshua Billings, Fiona Macintosh, Katherine Harloe, Oliver Taplin, Phiroze Vasunia and Emily Wilson for their help and advice. Special thanks to Constanze Güthenke, Glenn Most and Simon Goldhill and the readers for the journal for their extensive and illuminating comments on this piece.

I Marx (2002) I9. 'Hegel bemerkte irgendwo, daß alle großen weltgeschichtlichen Tatsachen und Personen sich sozusagen zweimal ereignen. Er hat vergessen, hinzuzufügen: das eine Mal als Tragödie, das andere Mal als Farce.' Marx (I869) I. 
question amongst scholars, but those, like Bruce Mazlish who have attempted to track it down suggest that Marx may have been recollecting with heavy distortion a remark that Hegel makes about the Roman Republic in his Philosophy of history. ${ }^{2}$ The source of Hegel's comments about the compulsive repetition of history may remain obscure, but it would certainly not be difficult to uncover the Hegelian genealogy of Marx's historical tropology here. Marx's characterisation of history as tragedy finds an echo in many of Hegel's writings from his youthful theological essays through the Phenomenology to his Aesthetics and the Philosophy of right. ${ }^{3}$ The Hegelian dialectic may have been conceived as a reaction to the historical events of the French Revolution, but its movement through thesis, antithesis and synthesis is explicitly connected to Hegel's analysis of tragedy. Hegel, in other words, does not so much use a tragedy such as Sophocles' Antigone to illustrate the dialectical development of the history of spirit; rather it is the dialectical movement which he uncovers as the essence of tragedy that becomes the master trope for understanding historical progress.

Karl Marx, then, in this passage at least, follows Hegel in transforming tragedy into a philosophy of history. Tragedy has become for Marx and Hegel a metahistorical text, its workings a grand narrative of historical progress. ${ }^{4}$ It is this background that makes sense of Slavoj Žižek's decision to entitle his latest analysis of the dual historical blows of 9/II and the 2008 financial crisis First as tragedy and then as farce. ${ }^{5}$ Žižek is at pains in his book to show how Marx's styling of the French Revolution as a tragedy in the Eighteenth Brumaire was not an isolated instance but rather the development of a more sustained 'rhetorical figure' haunting Marx's analysis of history. After commenting in 'A contribution to the critique of Hegel's philosophy of right' that 'it is instructive for [modern nations] to see the ancien régime, which in their countries has experienced its tragedy, play its comic role as a German phantom', Marx develops his analogy with antiquity further:

The Greek gods, who already died once of their wounds in Aeschylus's tragedy Prometheus Bound, were forced to die a second death - this time a comic one - in Lucian's dialogues. Why does history take this course? So that mankind may part happily with its past. We lay claim to this happy historical destiny for the powers of Germany. ${ }^{6}$

\footnotetext{
See Mazlish (1972).

See Paolucci and Paolucci (1962).

4 See White (1973) who identifies 'tragedy' as one of the dominant 'emplotments' of historical writing in the nineteenth century.

5 Žižek (2009).

6 Marx (I975) 247-8; quoted in Žižek (2009) 2. Marx and Engels (I976) 38I-2:
}

Es ist lehrreich für sie, das ancien régime, das bei ihnen seine Tragödie erlebt, als deutschen Revenant eine
Komödie spielen zu sehen. [...] Die Götter Griechenlands, die schon einmal tragisch zu Tode verwundet
waren im gefesselten Prometheus des Äschylus, mußten noch einmal komisch sterben in den 
It is this translation by Marx and Hegel amongst others of tragedy into a privileged heuristic category in philosophical thought which probably led George Steiner to make the claim:

\begin{abstract}
The major philosophical systems since the French Revolution have been tragic systems. They have metaphorized the theological premise of the fall of man. The metaphors are various: the Fichtean and Hegelian concepts of self-alienation, the Marxist scenario of economic servitude, Schopenhauer's diagnosis of human conduct as harnessed to coercive will, the Nietzschean analysis of decadence, Freud's narrative of the coming of neurosis and discontent after the original Oedipal crime, the Heideggerian ontology of a fall from the primal truth of Being. To philosophize after Rousseau and Kant, to find a normative, conceptual phrasing for the psychic, social, and historical condition of man, is to think 'tragically'.?
\end{abstract}

For Steiner it would be impossible to understand the history of ideas in the nineteenth and twentieth centuries - in the West, at least - without reference to tragedy. From Hegel to Freud, the great thinkers of modernity have accorded tragedy a central position in the development of their key ideas. In the same way that Hegel's I807 analysis of Antigone in the Phenomenology of spirit became emblematic of the nineteenth-century's obsession with Sophocles' heroine, Freud's outline of the Oedipus complex in his Interpretation of dreams, published in I900, casts a long Sophoclean shadow over the twentieth century. So from Marx and Hegel's claims about the inescapable tragedy of historical progress to Freud's shocking diagnosis that 'we are all Oedipus', Greek tragedy and the history of ideas had seemingly become inseparable.

But if tragedy has become, since the start of the nineteenth century, what LacoueLabarthe has called a 'figure in and of philosophy', ${ }^{8}$ it still remains to be seen what role this philosophy of the tragic has actually played in our understanding of tragedy. In other words, if we are interested in understanding what tragedy means to modernity, we may still need to ask ourselves what role this history of reading has played in the changing conceptualisation of tragedy. For while Steiner seems to suggest that the co-option of tragedy into the philosophical systems of the West has been absolute, the same cannot

Gesprächen Lucians. Warum dieser Gang der Geschichte? Damit die Menschheit heiter von ihrer Vergangenheit scheide. Diese heitere geschichtliche Bestimmung vindizieren wir den politischen Mächten Deutschlands.

On this passage see also Prawer (I976) 64-5.

7 Steiner (I984) 2.

8 Lacoue-Labarthe (2003) 8. On the broader exploration of the 'philosophy of the tragic', see Szondi (2002), Schmidt (2001), Eagleton (2002), Lambropoulos (2006) and Bohrer (2009). Silk (I996) provides a good starting point for an exploration of the relationship between tragedy and 'the tragic' within Classical scholarship. Judet de la Combe (20I0) is the latest attempt by a classicist to understand how the German philosophical reading of tragedy can contribute to our understanding of the genre today. Rokem (2009) and Puchner (20I0) both explore the dialogue between theatricality and philosophy and touch upon many of the central themes of this article from illuminatingly different perspectives. 
be said about the co-option of the philosophy of the tragic into the scholarly understanding of Greek tragedy. Indeed, I would argue, that the last thirty years of Classical scholarship at least have been characterised by resistance not just to individual figures in this philosophical tradition but to the whole modern philosophical engagement with tragedy as such. Glenn Most provides an exemplary account of the problems facing classicists today:

When we think of 'tragedy' nowadays, it seems difficult to keep entirely separate two categories that are in fact distinct: the largely formal criteria of the literary kind 'tragedy', and issues of content and meaning we tend to associate rather with the idea of the 'tragic'; the specific genre of 'tragedy' seems to be linked in a peculiar way with a determinate ethos, a 'tragic' vision of the world, which finds its most appropriate expression in that very genre. In other words we expect a 'tragedy' to be 'tragic'. This expectation may sound self-evident, but in fact this 'tragic' ethos is a modern construction, one whose links to the ancient genre of Greek 'tragedy' are far more tenuous than its connections to philosophical and social developments over the last two centuries. ${ }^{9}$

In a similar vein, Simon Goldhill seems to caution against the seductions of philosophy:

The long tradition of Western writing about tragedy might make it seem natural for critics and artists to reach toward an abstract and general concept of the 'the tragic' [...]. The lure of seeking such a general and abstract understanding is evident, especially for nineteenth-century German thought and its heirs today. But, as ever, what seems natural has a full cultural history behind it. ${ }^{\text {Io }}$

But who exactly are these heirs 'of German thought' that Goldhill seems so confident in identifying? And perhaps more interestingly, if Goldhill seeks to historicise a tradition of reading that he thinks has become naturalised in the wake of German idealism, would it not also be possible to historicise Goldhill's own suspicion of this tradition? Although I am not proposing that we go all the way back to Plato to trace the history of this old quarrel between poetry and philosophy, it does seem important to contextualise Goldhill's mistrust of the abstract here.

It is not by chance that Goldhill's provocation to think beyond the tragic is made in the name of history. For it was under the banner of the historical specificity of tragedy that Goldhill's intellectual predecessor, Jean-Pierre Vernant, formulated one of the most compelling renunciations of the German theorisation of tragedy in Classical scholarship. Vernant's essay 'Oedipus without the complex' launches a full frontal attack on perhaps

9 Most (2000) 20.

Io Goldhill (2008) 45. Contra Goldhill and Most, Silk (1996) 6 writes 'in the wake of the theoretical discussions just referred to, "the tragic" is a concept of central concern to everyone who wishes to come to terms with tragedy, Greek or other.' 
the single most influential reading of Greek tragedy in the last two hundred years. Where 'abstraction' and 'generalisation' are the source of worry for Goldhill, it is the 'universalism' of the Freudian reading that Vernant finds so problematic:

In the Freudian interpretation this historical aspect of tragedy remains totally incomprehensible. If tragedy draws its material from a type of dream that has universal significance, if the impact of tragedy depends on stimulating an emotional complex that we all carry within us, then why was tragedy born in the Greek world at the turn of the fifth and sixth centuries? Why did other civilizations know nothing of tragedy? And why was the tragic seam so rapidly exhausted in Greece itself and its place taken by a philosophical type of thought that did away with contradictions upon which tragedy constructed its dramatic universe, by accounting for them rationally? ${ }^{\text {II }}$

One of the most striking elements of Vernant's analysis here is his identification of Freud's rather specific reference to Oedipus in course of a chapter in the Interpretation of dreams devoted to typical dreams with a general theory of tragedy. Rather than restricting his critique to Freud's reading of this particular Sophoclean play, Vernant assigns to Freud a theory of the tragic, which by a clever sleight of hand places it in continuity with a tradition of German thought that leads back to Schelling and Hegel. I have no doubt that Vernant is right that Freud is indebted to these figures as Peter Rudnytsky's excellent book on Freud's Oedipus, amongst others, has made clear. ${ }^{12}$ And yet, to associate Freud's formulation of the Oedipus Complex in the Interpretation of dreams with a full blown theory of the tragic à la Hegel or Nietzsche is a different kind of gesture. ${ }^{13}$ In other words, while critiquing Freud for his universalising reading of Sophocles' Oedipus, Vernant universalises Freud's reading of Oedipus into a full blown philosophy of the tragic. Freud, then, is not so much criticised by Vernant for his psychologisation of a fictional character or for his lack of attention to the Greek conceptualisation of the self as he is for not comprehending the historical specificity of the emergence of the genre of tragedy. As much as Freud's interpretation of the content of the myth, Vernant objects to Freud's starting point. 'Oedipus Rex', Freud claims, 'moves a modern audience no less than it did the contemporary Greek one'. ${ }^{14}$ For Vernant such a statement is nonsensical. 'Other civilizations', according to Vernant, 'know nothing of tragedy'. The experience of tragedy is so exclusive to its fifth-century audience that Vernant can make the claim that

II Vernant and Vidal-Naquet (i988) 89-9o.

I2 See Rudnytsky (I987), Armstrong (2005) and Bowlby (2007).

I3 I am not suggesting that Freud was merely interested in the myth of Oedipus and had no broader interest in tragedy as such. Indeed the introduction of the discussion of Oedipus in the Interpretation of dreams where Freud explores Sophocles' relationship to what he calls the 'tragedy of destiny' (Schicksalstragödie) demonstrates his broader interest in tragedy and the tragic. Freud does not, however, formulate a theory of tragedy in the manner of the German Idealists or Nietzsche after them. On Freud, Aristotle and tragedy see Ramazani (I99I).

Freud SE 4, 262. 
in the fourth century 'Aristotle can no longer know what the tragic consciousness or tragic man really are'. ${ }^{15}$ And if Aristotle could not understand tragedy, what chance does Freud have? What chance, one might wonder, does Vernant think he has?

The irony of Vernant's extreme historicism, however, emerges when one considers that his own narrative of the birth, flourishing and death of tragedy at the hands of rationalism resonates strongly with the account of a figure who is more often associated with the dismantling of historicism than its painstaking preservation. The echoes of Nietzsche's provocative exploration of the birth and death of tragedy in Vernant's strongly historicising analysis are striking. For Vernant, like Nietzsche, the essence of tragedy gives way to a new order of philosophical inquiry governed by the principles of reason. Although his own account singles out Aristotle, Vernant's description has more in common than he might want to admit with Nietzsche's lament of the advent of Socratism: 'Socratism is the murderous principle [...] we may identify Socrates as the opponent of Dionysos'. ${ }^{16}$ For both Vernant and Nietzsche, then, the death of tragedy is firmly laid at the hands of philosophy.

And yet, as Nicole Loraux has written: 'Jean-Pierre Vernant and Pierre Vidal-Naquet continue a long erudite tradition which completely opposes the Nietzschean reading which, in fact, they never cite. ${ }^{17}$ In her later work Loraux herself launched a spirited attack on a disciplinary orthodoxy which she had herself played a crucial role in constructing. In promoting an understanding of tragedy as an essentially civic institution, Loraux, like Vernant, had contributed to exiling Nietzsche's voice from the debate about the tragic genre. A corollary of this position, as we have seen, had been an investment in the historical specificity of tragedy inspired in part by a quasi-Marxist historicism. The now classic statement of this new orthodoxy was put forward in the edited collection Nothing to do with Dionysos: Athenian drama in its social context, published in 1990 with an essay by Loraux. ${ }^{18}$ But in a move which strikes me as both bold and significant Dionysus is made to stand in for the civic realm and Nietzsche is barely mentioned at all. The book could just as well have been called 'Nothing to do with Nietzsche'! When Loraux takes Oliver Taplin to task in The mourning voice for arguing that there is nothing 'intrinsically Dionysiac about tragedy', her criticism could extend to the body of Classical scholarship for whom there could be nothing intrinsically or even extrinsically Nietzschean about tragic criticism. ${ }^{19}$ Nietzsche, it would seem, had been marginalised for a number of political as well as disciplinary reasons and Loraux's return to him is all the more striking because she was herself complicit with his exclusion.

I5 Vernant and Vidal-Naquet (I988) 89. Despite Vernant's attention to historical specificity, it is interesting that he seems to inherit a notion of 'the tragic' in his claim that Aristotle could not understand 'the tragic consciousness'. Perhaps, after all, he is one of Goldhill's 'heirs' to German idealism.

I6 Nietzsche (I999) 64.

I7 Loraux (I973) 909-10 n. 6.

I8 Winkler and Zeitlin (I990).

I9 Loraux (2002) 83. 
Nietzsche, then, plays a fascinatingly complex role in this debate about the philosophical reading of tragedy. On the one hand, his own work The birth of tragedy has become associated with the philosophy of the tragic made suspect by Classical scholars who have been wary of its dehistoricising tendencies. Of course, Nietzsche, saw himself opposing the abstraction and idealism of previous philosophical analyses of the genre. And yet, subsequent classicists have tended to take at face value Wilamowitz's critique which depicted Nietzsche's text as the opposite of historically minded, philologically precise Altertumswissenschaft. ${ }^{20}$ On the other hand, at the heart of Nietzsche's own work is a critique of philosophy as the antithesis to the tragic aesthetic. ${ }^{2 \mathrm{I}}$ The distaste for the philosophical approach to tragedy in modernity has its mirror-image in a suspicion of the ancient philosophical tradition - a suspicion grounded in the accusation that the combined forces of Socrates, Plato and Aristotle had a role to play in tragedy's demise.

The marginalisation of Aristotle has been a marked phenomenon in the recent study of tragedy. When Lessing claimed in his Hamburg dramaturgy that the laws laid down by Aristotle in the Poetics were as certain in their application to the drama as Euclid's elements in geometry, ${ }^{22}$ he bore testimony to the unrivalled authority of Aristotle as a reader of tragedy at the close of the eighteenth century. Indeed, in the tradition of interpretation which preceded German idealism, it remained virtually impossible to read tragedy without reference to the Poetics. ${ }^{23}$ The reasons for the side-lining of Aristotle in modern criticism are no doubt complex. At one level, this late twentiethcentury rejection could be seen as the heir to a suspicion that has its genesis in German idealism, was formalised by A. W. Schlegel in his Vienna lectures of I808, and had its culmination in Nietzsche's concerted attempt to eradicate Aristotle from the theory of tragedy. ${ }^{24}$ The post-war critiques of Aristotle, nevertheless, appear to have a distinctive flavour. In Vernant, as we saw, Aristotle's credentials as a reader of tragedy are dismissed almost as an accident of chronology. Because Aristotle wrote in the fourth not the fifth century he found himself incapable of understanding tragic consciousness. Edith Hall, for her part, has argued that there is a striking absence of awareness of the political dimension of tragedy in Aristotle's Poetics: 'Aristotle not only leaves out of his treatise the collective, civic context of the performance of Greek tragedy, and the Athenocentricism of its subject matter and perspective. His agenda seems to have involved the complete erasure from tragedy of even the abstract idea of the polis as an institution - whether Athenian, democratic, or otherwise. ${ }^{25}$ As concerns

\footnotetext{
20 See Silk and Stern (I98I).

2I For Nietzsche's complex relationship to philosophy see Wininger (I997).

22 Lessing (1962) 263. On Lessing and Aristotle, see Kommerell (1970).

23 Cave (I990) gives a fascinating account of the legacy of the term anagorisis from the Poetics. Halliwell (2002) discusses the reception of Aristotle's discussion of mimesis. Eagleton (2002) II ff. and Lurie (20I2) give a broader picture.

24 See Silk and Stern (I98I) 225-39 for an account of Nietzsche's ambivalent relationship to the Poetics.

25 Hall (I996) 296.
} 
about the historical specificity and civic preoccupations of tragedy have been prioritised, so have Aristotle's fortunes as an authority on tragedy waned.

But there is a further dimension to this conflict between philosophy and tragedy in antiquity and modernity. According to Goldhill: 'Aristotle is repeatedly taken as the father of the tragic as theoretical abstraction'. ${ }^{26}$ Aristotle in his dehistoricising, depoliticising reading of tragedy, on this account, stands as the head of a tradition that has its culmination in Schelling, Hegel, Nietzsche and Freud. And yet, according to Goldhill, such an assimilation of Aristotle to the modern philosophy of the tragic is misguided. Aristotle, according to Goldhill, may have come up with an abstract definition of the genre of tragedy but he did not define 'the essence of the tragic'. For, as Glenn Most argues: 'In ancient philosophy and literary criticism, there seems to have been nothing whatsoever corresponding to the modern philosophical notion of "the tragic" as a fundamental dimension of human experience; there were instead only theories of "tragedy" as a specific genre'. ${ }^{27}$ Most and Goldhill could be thought to be making a distinction between a modern philosophy of the tragic and an ancient philosophy of tragedy. But by laying emphasis on the formalist approach adopted in the Poetics, they seem to go further and deny that Aristotle saw anything intrinsically philosophical about the poetic genre of tragedy. Although, as a philosopher, Aristotle may adopt a philosophical approach to tragedy, the genre of tragedy has no inherent relationship to philosophy. This position has had some currency despite the fact that Aristotle insists that tragedy and philosophy precisely in their abstraction and their universalism share a methodology: 'Poetry', Aristotle affirms during the course of his discussion of tragedy, 'is a more philosophical and a higher thing than history: for poetry tends to express the universal (ta katholou), history the particular' (Poetics I4I5b). ${ }^{28}$ Moreover, although Aristotle's unsurpassed influence in the history of reading tragedy relies to some extent on his formalist insights, it is the ethical implications of the analysis of catharsis that have been central to his reception. When Peter Szondi famously remarked 'Since Aristotle, there has been a poetics of tragedy. Only since Schelling has there been a philosophy of

26 Goldhill (2008) 49. See for instance Bohrer (2009) I3 who himself rejects a philosophical reading of tragedy in favour of an 'aesthetic' one, but nevertheless assimilates Aristotle and Hegel and criticises both for their overly 'conceptual' readings of tragedy:

Beide Philosophen sehen Poesie letztlich in Begriffen aufgehen: Aristoteles' Reduktion der Metapher auf Denken und Hegels' Vernachlässigung der Affekte zugunsten spekulativer Sätze hat zur Folge, dass sie die Pathosformen der Tragödie nicht als autonome Rede ansehen.

Most (2000) 24. See also Goldhill (2008) 47 '[tragedy] does not seem to imply a worldview or a metaphysics' in Aristotle.

28 In this famous passage Aristotle makes two separate but related claims about poetry in its opposition to history: (I) that it deals with hypotheticals or probabilities, what he calls to eikos, rather than 'actual events' (2) that it relates to the 'universal', ta katholou, rather than to particulars. Commenting on this passage, Most (2000) 24 argues 'tragedy may well be more philosophical than history, but is certainly less philosophical than philosophy'. Most is clearly right that Aristotle is not equating poetry and philosophy in any simple way but what I find significant is that Aristotle locates the (relative) claim to kinship with philosophy in poetry's relationship to the hypothetical and to the universal. 
the tragic', ${ }^{29}$ he ignores the fact that it was a rereading of Aristotle as much as a rereading of Sophocles that led to the first formulations of a philosophy of the tragic in German Idealist thought.

As I see it, there are a number of implications that arise from this much too brief and schematic account of the relationship between tragedy and the history of thought. For one, I see a complex overlaying of ancient and modern in this narrative. On the one hand, in Szondi's, Most's and Goldhill's account there is a clear historical break between antiquity and modernity. The philosophy of the tragic, on this account, is intrinsically bound up with the concerns of modernity and bears only a superficial relationship to the philosophical reception of tragedy within antiquity. In fact, at its most extreme, this account appears to deny that there was a philosophical understanding of tragedy within antiquity at all. ${ }^{30}$ Not only is Aristotle's analysis reduced to formalism, there is a suggestion that there is nothing particularly philosophical about ancient tragedy per se; some tragedies appear to express preoccupations with more or less philosophical implications but the genre as such is considered as a phenomenon of literary history rather than being integral to the history of ideas. Indeed, one of the reasons why scholars have been reluctant to engage with this modern reception of tragedy has been this perceived discontinuity between ancient and modern concerns.

On the other hand, it is Aristotle's association with this philosophical tradition and its failure to engage in the historical and social conditions of the performance of tragedy in the fifth century which accounts for his marginalisation in recent studies. It is because the modern philosophy of the tragic has become suspect to scholars who are concerned to highlight the political and civic dimension of ancient tragedy that Aristotle's all too abstract and universalist reading has become problematic. In Vernant's account, both Freud and Aristotle are equally guilty of anachronism. But in the ultimate irony we find Vernant criticising Freud and Aristotle for their anachronistic preoccupations in words which could have been lifted from Nietzsche's Birth of tragedy. So not only has the question of whether or not tragedy has a relationship to philosophy always already been bound up in its modern philosophical reception, the modern philosophical reception of tragedy establishes for itself a genealogy which leads back to antiquity. Exploring the relationship between tragedy and the history of ideas demands, then, to quote Charles Martindale following Eliot, that we 'respect not only the presentness of the past but also its pastness, and not only the pastness of the past but also its presentness' ${ }^{3 \mathrm{I}}$

29 Szondi (2002) I. Seidensticker (1996) rejects Szondi's schematisation arguing from a different perspective for Aristotle as a philosopher of the 'tragic'. Halliwell (1996) 332 agrees with Most and Goldhill that Aristotle's Poetics cannot be viewed as theorisation of the 'tragic' and elects Plato as 'the first conscious delineation of the tragic'.

30 Thus Most (2000) 23: 'Aristotle treats tragedy as a species of poetry, not philosophy. On his view, tragedy does not convey a profound vision of the world and of the individual's place in it, which only happens to be expressed contigently in a poetic medium'.

3I Martindale (1993) 7. 
But behind this intricate layering of antiquity and modernity in debates about the philosophical import of tragedy lie some of the most important methodological questions for the study of ancient texts. How do we make sense of the historicity of reading, on the one hand, and at the same time account for the seemingly universal appeal of the classics to different readers in different historical circumstances, on the other? How can reception simultaneously do justice to the historical circumstances of the original production of these plays and reveal the historical contexts of their subsequent appropriations? Can one both understand Hegel's influence on the way we read tragedy today and understand what it was about ancient tragedy that made it mean something to Hegel (and to us) beyond this history of reading? Any account of the reception of tragedy seems to me have to deal at least implicitly with these questions.

One of the most influential strands of recent reception studies, the history of performance of Greek tragedy, seems to me to be negotiating many of these same issues. It is perhaps no coincidence that it was the performance aspect of tragedy which captured the attention of the very Classical scholars who had been so instrumental in highlighting the importance of the original performance context of these plays. ${ }^{32}$ That it was the history of performance and not the history of ideas which took centre stage in Classical reception studies on tragedy may be related to the historicist instincts of Classical scholarship. There appears to be a parallel: while for classicists it became essential to study the social, political and historical context of fifth-century performances of Greek drama, for reception scholars there was the same imperative to contextualise the contemporary performance of these plays. It is almost as if scholars hoped that by undertaking an exhaustive cultural analysis of the more recent performances they could by proxy experience the original in the theatre of Dionysus itself. Nevertheless, despite the obvious connection between performance and historical experience, a universalising logic still underpins this approach. Because these plays were originally experienced as performances, they should still be experienced as such today and there is, at the very least, an implicit assumption that this experience of performance is in some senses a transhistorical one. But just as Vernant and the contributors to Nothing to do with Dionysos showed little concern for the philosophical reception of the ancient plays in figures like Aristotle, so too modern scholars of performance history tend to play down the importance of the philosophy of the tragic in their analyses of tragedy today. In the same way that I believe it is misguided to disregard Plato and Aristotle as readers of tragedy in antiquity, so I would argue that we all watch these plays today to some extent through the prism of Hegel, Nietzsche and Freud. In a manner, then, perhaps more complex and convoluted than George Steiner might suggest, the history of thought and the meaning of tragedy today are inextricably linked.

In the remainder of this article I want to give some flesh to this rather abstract and overgeneralising material by looking again at two recent receptions of Greek tragedy

32 I am thinking here, in particular, of the invaluable work which has come out of the Oxford Archive of Performances of Greek and Roman Drama. 
which seem to me to exemplify some of these methodological problems. Luce Irigaray's reading of Antigone and Hélène Cixous' reception of the Oresteia self-consciously position themselves in relation to the modern philosophy of the tragic but both seem to reject its abstractions and universalising assumptions. For both Irigaray and Cixous the materiality of language, in particular, the materiality of tragic language, provides a way of escaping the oppressive idealism of the philosophy of the tragic. For both these writers, however, their resistance to abstraction is articulated in a vocabulary which acknowledges the legacy of tragedy in a powerful history of thought extending back to German idealism. What Irigaray and Cixous share with Classical scholars is a desire to restage the ancient quarrel between poetry and philosophy but, unlike these scholars, they both acknowledge the impossibility of reading outside the framework of this contest between abstraction and poetics.

The necessity of the mediation of tragedy through a history of thought both ancient and modern is signalled from the start in Irigaray's reading of Antigone. Irigaray positions her exploration of tragedy in her great work Speculum of the other woman between her devastating critique of the phallocentrism of psychoanalysis and her acrobatic deconstruction of Plato's Republic. Antigone takes her place in Irigaray's text between Freud's phallus and Plato's womb. Moreover, she prefaces her analysis of Sophocles with a long epigraph from Hegel's Philosophy of nature:

On the one hand the uterus in the male is reduced to a mere gland, while on the other, the male testicle in the female remains enclosed within the ovary, fails to emerge into opposition, and does not become an independent and active cerebrality. The clitoris, moreover, is inactive feeling in general; in the male on the other hand, it has its counterpart in active sensibility, the swelling vital, the effusion of blood into the corpora cavernosa and the meshes of the spongy tissue of urethra. [...] On account of this difference therefore, the male is the active principle; as the female remains in her undeveloped unity, she constitutes the principle of conception..$^{33}$

With its strong echoes of Aristotle's biology, Hegel's text signifies the importance of a relationship between the abstract and the material in Irigaray's reception of Sophocles. For Irigaray, the mutual implication of biology and politics, nature and culture, Hegel and Aristotle, are all at stake in her understanding of Antigone. ${ }^{34}$ And it is precisely the movement from the material to the abstract, the very movement that has been at stake in the co-option of tragedy into the history of philosophy, which is at the core of Irigaray's reading of Antigone:

The purpose that moves blood relatives to action is the care of the bloodless. Their inherent duty is to ensure burial for the dead, thus changing a natural phenomenon

33 Hegel (1970) I75, quoted in Irigaray (1985) 2I4; Irigaray (1974) 266.

34 For a more detailed analysis of this passage see Chanter (1995) II9-20 and Wilmer and Zukauskaite (2010) 4-5. 
into a spiritual act. One more step (into negation) and we see that it is the task of womankind, guardian of the blood tie, to gather man into his final figuration, beyond the turmoil of contingent life and the scattered moments of Being-there. Man is thereby raised into the peace of simple universality. ${ }^{35}$

Irigaray demonstrates how Antigone's act becomes abstracted first through her exemplification as 'womankind' (féminité) and then through its co-option into 'simple universality'. She thus traces in Antigone's reception a movement which transforms her individual plight into a universal philosophy. As this brief opening quotation makes clear, Irigaray's reading is only really intelligible through its relationship to Hegel. Irigaray's vocabulary of 'spirit', 'negation' and 'universality' are explicit citations of the Hegelian text. Even her emphasis on blood and her implicit characterisation of Hegel's reading as bloodless are in fact a homage to the Hegel passage she cites in the opening paragraph. Certainly, Irigaray is driven in her reading by a deconstructive urge to reveal how Antigone exceeds her idealising reading in Hegel. But in a gesture which she shares with Derrida and which she uses to such devastating effect in her reading of Plato, it is in the terms which she derives directly from Hegel himself that Irigaray seeks to deconstruct his interpretation. Irigaray's reception of tragedy seems, then, to be a confirmation of the inescapable legacy of a particular history of thought. If her approach to tragedy suggests anything, it is the difficulty of articulating a position outside the vocabulary of the philosophy of the tragic.

And yet, at other moments, Irigaray's strategy is articulated precisely in terms of a resistance to this teleology. 'It is very important' she writes 'to question the foundation of our symbolic order in mythology and in tragedy, because they deal with a landscape which installs itself in the imagination and then, all of a sudden, becomes law'. ${ }^{6}$ And at one level at least, in the Speculum she appears to identify this locus of resistance in the Sophocles text itself. For Irigaray, the movement towards the establishment of the law, the law of patriarchy one assumes, postdates the original moment of Antigone's literary production: 'Certainly,' she writes, 'in the work of Sophocles, which marks the historical bridge between matriarchy and patriarchy, things are not yet clear. ${ }^{37}$ Irigarary has been criticised by classicists for her provocative reference to a 'historical bridge' here. ${ }^{38}$ The conception of a historical matriarchy has been revealed to be at least as much an

35 Irigaray (I985) 2I4. Irigaray (I974) 266-7:

Le parent par le sang a comme but de son action le soin de l'exsangue. Son devoir intrinsèque est d'assurer la sépulture du mort, transformant ce phénomène naturel en acte spirituel. Un pas de plus et on saura que c'est à la féminité, gardienne du lien au sang, que revient de recueillir dans sa figuration achevée, hors de l'inquiétude de la vie contingente et de la succession de son être-là dispersé, la virilité ainsi élevée à la paix de l'universalité simple.

36 Baruch and Serrano (I988) I59.

37 Irigaray (I985) 217; Irigaray (I974) 270: 'Certes, chez Sophocle, soit dans ce passage historique en voie d'achèvement du matriarcat au patriarcat, les choses n'était pas encore aussi claires.'

$3^{8}$ Goldhill (2006) I42. For a different account of the role of this 'originary' moment see Schwab (2010). 
ideological construct of modernity as it was an instrument of phallocratic ideology in antiquity. Goldhill goes as far as accusing Irigaray of 'intellectual hooliganism' for making such a crassly ahistorical statement in the name of history. 39

Irigaray's fellow feminist Hélène Cixous, however, makes an almost identical move in her analysis of Aeschylus' Oresteia in Sorties: 'How hard it all is for Orestes who is at the turning point in time and whose action, a matricide - until now the crime of crimes - marks the end of mothers and inaugurates the sublime era. ${ }^{40}$ Cixous' manipulation of the discourse of history is even more playful here. By using the present tense in identifying with Orestes, Cixous gives a sense of a history that is not yet determined and is still in play: 'until now', she writes, 'the crime of crimes'. But elsewhere in Sorties, Cixous seems to reflect more self-consciously on this strategy:

One can ramble on for a long time about hypothetical prehistory and matriarchal epoch. Or, like Bachofen, one can attempt to prefigure a gynarchic society, drawing from it poetical and mythical effects, which have a powerfully subversive impact regarding the history of the family and male power. ${ }^{4 \mathrm{I}}$

Cixous, in other words, explicitly reveals the interest that feminists might have in perpetuating the 'intellectual hooliganism' inherited from J. J. Bachofen and Friedrich Engels. Indeed, it is this wilful reappropriation of Bachofen and his myth of matriarchy which frames her whole reading of the Oresteia under the heading of the 'Dawn of phallocentrism'. But like Irigaray, the conception of history itself seems to be at stake:

All the ways of differently thinking the history of power, property, masculine domination, the formation of the State, and the ideological equipment have some effect. But the change that is in process concerns more than just the question of 'origin'. There is phallocentrism. History has never produced or recorded anything else - which does not mean that this form is destinal or natural..$^{22}$

39 Goldhill (2006) I42.

40 Cixous (1996) I03. Cixous (2010) I47: 'Comme tout est difficile pour Oreste qui se trouve à la charnière du temps, et dont le geste, un matricide, jusqu'à lui le crime des crimes, va signer la fin des mères et inaugurer l'ère sublime!'

4I Cixous (1996) 82. Cixous (2010) 108-9:

On peut divaguer longtemps sur une hypothétique préhistoire et sur une époque matriarcale. On peut, comme le fit Bachofen, tenter de refigurer une société gynéocratique, d'en tirer des effets poétiques et mythiques à portée puissamment subversive quant à l'histoire de la famille et du pouvoir mâle.

Toutes les façons de penser autrement l'histoire du pouvoir, de la propriété, la domination masculine, la constitution de l'État, l'appareillage idéologique ont une efficacité. Mais le changement en cours n'a que faire de la question de 'l'origine'. Il y a du phallocentrisme. L'histoire n'a jamais produit, enregistré que ça. Ce qui ne veut pas dire que cette forme est destinale ou naturelle. 
Where Classical scholars such as Vernant had sought in history a position from which to critique philosophy, Cixous and Irigaray argue that there has never been a conception of history which could stand outside the 'history of power, property, masculine domination', that is, also the history of philosophy. But nevertheless, the fact that history has always coincided with phallocentrism is not a product of nature or destiny, it remains contingent. Irigaray and Cixous, then, in their provocative manipulations of the discourse of history challenge the naivety of any appeal to history which affirms its ability to stand outside the grips of ideology. And yet, in their respective attempts to wrest Antigone and Orestes away from the oppressive teleology of their co-option into patriarchal philosophy, they both turn to history. Cixous' complex temporality here is a compelling way of understanding the continuing power of tragedy today. In Cixous' jumbled up chronology, Aeschylus would already have read Bachofen and Engels and yet, simultaneously, we are all of us, Bachofen and Engels included, still trying to catch up with Aeschylus. Orestes and Electra are suspended for Cixous in an eternal present but it is a present which acknowledges the complex overdetermination of history.

If Aristotle and Hegel are the starting points for Irigaray's interpretation of the Antigone, then Freud and Joyce stand at the threshold of Cixous' reading of the Oresteia in Sorties. She takes as her two epigraphs a passage from Freud's Moses and monotheism and Joyce's Ulysses. What is so significant about this choice is that Cixous not only seems to make the claim that we cannot read Aeschylus without a history of reading that would include both Freud and Joyce, but she also explicitly addresses the question of abstraction and idealism in her choice of quotations. The passage from Freud's Moses that she chooses comes from a chapter which develops the argument about the 'advance in intellectuality' (der Fortschritt in der Geistigkeit) of the Jewish people through an analogy with Greek tragedy:

Under the influence of external factors into which we need not enter here and which are also insufficiently known, it came about that the matriarchal social order was succeeded by the patriarchal one - which, of course, involved a revolution in the juridical conditions that had so far prevailed. An echo of this revolution seems still to be audible in the Oresteia of Aeschylus. But this turning point from mother to father points in addition to a victory of intellectuality over sensuality (einen Sieg der Geistigkeit über die Sinnlichkeit) that is, an advance in civilization (einen Kulturfortschritt), since maternity is proved by the evidence of the senses while paternity is a hypothesis, based on an inference and a premise. Taking sides in this way with a thought-process (Denkvorgang) in preference to a sense perception (sinnliche Wahrnehmung) has proved a momentous step. ${ }^{43}$

It is to the Oresteia and its decisive redistribution of gender roles that Freud turns to ground his account of the intellectual advance of the Jewish people. ${ }^{44}$ The triumph of 'intellectuality' over

43 Freud SE 23, II3-I4; Freud (1939) 202.

44 For an analysis of this passage in terms of Freud's 'matriarchy manqué', see Armstrong (2005) 244-9. 
'sensuality' which Freud saw as key to the advance in civilisation represented by the Greeks has the same relationship to the development of abstract thought that Freud sees as Moses' gift to the Jews. By juxtaposing her own reading of tragedy to Freud's genealogy of the advent of idealism, Cixous seems to make this relationship between the intellect and the senses the central question of tragedy. Recalling Irigaray's own thematic of blood which she develops in her analysis of the Antigone, Cixous asks: 'What value does blood have? What is the value of words? In the struggle between Blood and Words, the marriage pact - a commitment made with word and will - is stronger, Apollo claims, than the blood-tie. The link to mother loosens. The link to word tightens. We are still in the age of the organic. From now on legality is to come to the assistance of the father's order. A new relationship between body and justice will have to be instituted'. ${ }^{45}$ In Cixous' version Aeschylus' Oresteia is simultaneously the product and the origin of Freud's Moses and monotheism. By prefacing her reading of Aeschylus with the quotation from Freud she reveals the decisive role that the Freudian reception has played in our understanding of Greek tragedy. On the one hand, she implies, it is impossible to understand the gender politics of the Oresteia without acknowledging the role of Freud in determining our understanding of the text today. On the other hand, it is the relationship to the Oresteia that Freud constructs in his writing, a relationship which Freud construes as a natural one, that Cixous attempts to distrupt: 'And one day - as Freud sees it still inscribing itself in the Oresteia - the matriarchy is done for'. ${ }^{46}$ It is the contingency of the Freudian reading which Cixous wants to reveal. Far from an inevitable genealogy, Cixous tries to expose the arbitrary nature of the Freudian teleology. 'One day matriarchy is done for.' This is no necessary progress in civilisation, no triumphant 'advance in intellectuality'. Where Freud represents the 'dawn of phallocentrism' as a bloodless revolution, Cixous wants to reveal the violence of the Freudian interpretation:

All the energy still jammed into this end of the after-Medean afternoon (après-Médée), at the twilight of matriarchy, is set free once and for all. Matriarchal shrapnel scatters. The scene soaks up blood diverted from its ancient matrilinear circulation. Orestes, neuter, neither masculine nor feminine, half-active, half passive, neither criminal nor not-guilty, signs the end of the great reign of mothers. Dawn of phallocentrism. ${ }^{47}$

45 Cixous (1996) I03-4. Cixous (2010) I47:

Quelle valeur a le sang? Quelle valeur a la parole? Lutte entre le Sang et la Parole: le pacte de marriage, engagement pris avec la parole et le vouloir, est plus fort, affirme Apollon, que le lien du sang. Le lien à la mère se détend. Le lien à la parole se tend. On est encore à l'époque de l'organique. Il faudra désormais que le juridique vienne au secours de l'ordre du père. Que s'instaure un nouveau rapport entre le corps et la justice.

46 Cixous (I996) I03. Cixous (2010) I47: 'Et un jour - comme Freud le voit s'inscrire encore dans L'Orestie - c'en est fait du matriarcat'.

Cixous (1996) I05. Cixous (2010) I47-50:

Toute l'énergie encore bloquée dans cette fin d'après-Médée, au crépuscule du matriarcat, est libérée, une fois pour toutes. Des éclats matriarcaux se répandent. La scène s'imbibe de sang détourné de son antique circuit matrilinéaire. Ce que le geste d'Oreste, neutre, ni masculin ni féminin, mi-actif, mi-passif, ni criminel 
Cixous' and Irigaray's resistant readings are like the 'matriarchal shrapnel' which erupt through the surface of not only Hegel's and Freud's text but Sophocles' and Aeschylus' texts too. In their hands, tragedy becomes a kind of écriture féminine capable of disrupting the inexorable march towards male idealism. But unlike Classical scholars who are committed to a fantasy which enables them to think they can return to these texts unsullied by Hegel and Freud (and Plato and Aristotle too for that matter), Irigaray and Cixous show how we can never read these texts unsullied by their previous interpreters. We are all dripping in the blood of previous readings. What is more, for both Irigaray and Cixous, the interest of Sophocles and Aeschylus are inevitably tied up with their subsequent reception in Hegel and Freud. The central importance of Greek tragedy for feminism is intimately bound up with its importance for the history of thought. But while it is fair to say that without the Hegelian and Freudian investment in tragedy its role in the modern history of feminism would not have been assured, that is not to say that the meaning of tragedy is co-extensive with these earlier interpretations. Hegel's and Freud's analyses of these texts were themselves mediated by a long history of reading, but this history of reading did not determine in a mechanistic way the meaning they were able to uncover in these texts. Hegel and Freud, just as Irigaray and Cixous, released their own idiosyncratic shrapnel from these plays.

What is so interesting about the feminist receptions is that they seem to expose the same conflict between abstraction and materialism, universalism and specificity, at the heart of the history of thought which we uncovered as the central preoccupation of scholars of tragedy today. Let us take the Freudian reading as an example. It is part of the provocation of the feminist reception to juxtapose Freud's writings about tragedy to those of Hegel. The power of Irigarary's reading of Antigone, for instance, lies to some extent in the realisation that an assault on Freud and Lacan lies behind the ostensible attack on Hegel. It is by rewriting the history of thought to include Hegel in a genealogy of the phallocentricism of psychoanalysis that Irigaray makes one of her most significant arguments. The conflation of the Freudian reading with German idealism is one of the most provocative elements of both Irigaray's and Cixous' analyses of tragedy. After all, it would be just as easy to argue that what Freud was doing in his radical reinterpretation of Oedipus was overthrowing the premise of idealism. Freud's Oedipus, after all, shares little in common with Hegel's description in the Philosophy of history:

In the Egyptian Neith, Truth is still a problem. The Greek Apollo is its solution; his utterance is: Man know thyself. In this dictum is not intended a self-recognition that regards the specialities of one's own weaknesses and defects (die Selbsterkenntniss der Particularitäten seiner Schwächen und Fehler): it is not the individual that is admonished to become acquainted with his own idiosyncrasy, but humanity in general (der Mensch überhaupt) is summoned to self-knowledge. This mandate was given to the Greeks,

ni non coupable, signe, c'est l'arrêt du grand règne des mères. Aube du phallocentrisme. 
and in the Greek Spirit humanity exhibits itself in its clear and developed form. Wonderfully, then, must the Greek legend surprise us, which relates, that the Sphinx - the great Egyptian symbol - appeared in Thebes, uttering the words: what is that which in the morning goes on four legs, at midday on two, and in the evening on three? Oedipus, giving the solution, Man, precipitated the Sphinx from the rock. The solution and liberation of that Oriental Spirit, which in Egypt had advanced so far as to propose the problem, is certainly this: that the Inner Being [the Essence] of Nature is Thought, which has its existence only in the human consciousness. ${ }^{48}$

In fact, it is almost as if Hegel is anticipating the Freudian reading when he warns: 'In this dictum is not intended a self-recognition that regards the specialities of one's own weaknesses and defects: it is not the individual that is admonished to become acquainted with his own idiosyncrasy, but humanity in general is summoned to self-knowledge.'

\section{Compare Freud:}

If Oedipus Rex moves a modern audience no less powerfully than it did the contemporary Greek one, the explanation can only be that its effect does not lie in the contrast between destiny (Schicksal) and human will (Menschenwillen), but it is to be looked for in the peculiar nature of the material on which that contrast is exemplified. There must be something which makes a voice within us ready to recognise the compelling force of destiny in the Oedipus, while we can dismiss as merely arbitrary such dispositions as are laid down in [Grillparzer's] Die Ahnfrau or other modern tragedies of destiny. And a factor of this kind is in fact involved in the story of King Oedipus. His destiny (Schicksal) moves us only because it might have been ours, because the oracle laid the same curse upon us before our births as upon him. It is the fate of all of us, perhaps, to direct our first sexual impulse toward our mothers, and our first hatred and our first murderous wish against our father. [...] We shrink back from him with the whole force of the repression by which those wishes have since that time been held down within us. While the poet, as he unravels the past, brings to light the guilt of Oedipus, he is at the same time compelling us to recognize our own inner minds, in which those same impulses, though suppressed, are still to be found..$^{49}$

Not only is Freud precisely locating our identification with Oedipus in what Hegel terms the 'specialities of one's own weaknesses and defects'; he is decidedly turning his back on the rational Oedipus, the Oedipus of supreme knowledge whose encounter with the Sphinx enacts the power of reason over unreason. Freud's Oedipus signals the end of humanism 
which locates the identity of Man in his self-knowledge. It is, of course, Oedipus' lack of selfknowledge which makes him a source of identification for Freud. Our post-Freudian humanity is located in the realisation of the limits of self-knowledge.

And yet, Irigaray, implicitly, and Cixous, explicitly, places Freud in a continuum with an Enlightenment pursuit of abstraction and universality. My interest is not so much in this more general observation, for this strategy of revealing the tenacity of the Enlightenment project in the thought of those, like Hegel and Freud, who have identified themselves as its critics is hardly original. My concern is with the role of tragedy in this negotiation. For tragedy enables both Irigaray and Cixous to reveal how even for Freud in the conflict between the material and the abstract, the particular and the universal, there is always an implicit hierarchy, a hierarchy which is ultimately destined to reinscribe the relationship between philosophy and patriarchy. The feminist receptions of Aeschylus and Sophocles bring the question of the philosophical import of tragedy to the fore. Cixous and Irigaray bring to light the element in these texts which resist their co-option into the so-called 'progress in intellectuality'. The role of tragedy in the history of thought has always been to some extent an attempt to explore the limits of this conception. Irigaray and Cixous are so successful in exposing the conflict between flesh and the ideal in their rewritings, because it is precisely this dialectic at the heart of tragedy which made it of such interest to both Hegel and to Freud. Classical scholars have been keen to ignore this selfconscious paradox within the history of ideas. By arguing that philosophical readings of tragedy ignore specificity in their appeal to universalism and flatten complexity in their search for abstraction, they fail to acknowledge how the conflict between the particular and the universal, the flesh and the ideal, has been at the heart of the philosophical reception of tragedy since antiquity.

Joshua Billings has written in a recent review of Pierre Judet de la Combe's work ${ }^{50}$ that 'to read tragedy philosophically is to pose the question of meaning to the works themselves' ${ }^{5^{\mathrm{I}}}$ I would say that the task of reading tragedy from the standpoint of philosophy has always been about exploring the limits of meaning as much as reaffirming its possibility. It seems to me to be self-evident that tragedy signifies to us today through its dialogue with the history of thought. But what the feminist receptions I have been exploring reveal is how this dialogue between literature and philosophy is most interesting when it is most contentious. Dennis Schmidt has argued that: 'The reappearance of the topic of tragedy... [within the modern history of thought] is contemporaneous with the arrival of the end of metaphysics as a possibility. ${ }^{52}$ From Hegel's and Marx's investment in tragedy as a way of understanding history, through Nietzsche's claim that reason itself killed off tragedy, to Freud's Oedipus as the hero of the unconscious, the relationship between tragedy and philosophy even within philosophy itself has never been an easy one. But this should not come as a surprise; one need only turn once again to Plato and Aristotle.

50 Judet de la Combe (2010).

$5 \mathrm{I}$ Billings (20I0).

52 Schmidt (200I) 78 . 


\section{Works cited}

Armstrong, Richard (2005) A compulsion for antiquity: Freud and the ancient world, Ithaca, NY.

Baruch, Elaine Hoffan and Serrano, Lucienne (eds.) (I988) Women analyze women, New York.

Billings, Joshua (20I0) Review of Pierre Judet de La Combe, Les tragédies grecques sont-elles tragiques? Théâtre et théorie, BMCR 20I0.II.40.

Bohrer, Karl Heinz (2009) Das Tragische, München.

Bowlby, Rachel (2007) Freudian mythologies: Greek tragedy and modern identities, Oxford.

Cave, Terence (I990) Recognitions: a study in poetics, Oxford.

Chanter, Tina (1995) Ethics of eros: Irigaray's rewriting of the philosophers, New York.

Cixous, Hélène (1996) 'Sorties', in Hélène Cixous and Catherine Clément, The newly born woman, 63-I34, London.

(2010) 'Sorties', in Le Rire de la Méduse et autre ironies, Paris, 69-197.

Eagleton, Terry (2002) Sweet violence: the idea of the tragic, Oxford.

Freud, Sigmund (I90o) Die Traumdeutung, Leipzig and Vienna.

(1939) Der Mann Moses und die monotheistische Religion, Amsterdam.

(1953-74) The standard edition of the complete psychological works of Sigmund Freud [SE], ed. and trans. by James Strachey et al., London.

Goldhill, Simon (2006) 'Antigone and the politics of sisterhood', in Vanda Zajko and Miriam Leonard (eds.) Laughing with Medusa: Classical myth and feminist thought, Oxford, I4I-62.

(2008) 'Generalizing about tragedy', in Rita Felski (ed.) Rethinking tragedy, Baltimore, 45-65.

Hall, Edith (1996) 'Is there a polis in Aristotle's Poetics', in Silk (I996), 295-309.

Halliwell, Stephen (1996) 'Plato's repudiation of the tragic', in Silk (1996), 332-47.

(2002) The aesthetics of mimesis: ancient texts and modern problems, Princeton, NJ.

Hegel, G. W. F (I902) The philosophy of history, trans. J. Sibree, New York.

(1970) Philosophy of nature, trans. M. J. Petry (London).

(I986) Vorlesungen über die Philosophie der Geschichte, Werke xii, Frankfurt

Irigaray, Luce (1974) Speculum de l'autre femme, Paris

(1985) The speculum of the other woman, Ithaca, NY.

Judet de La Combe, Pierre (20I0) Les tragédies grecques sont-elles tragiques?: théâtre et théorie, Montrouge.

Kommerell, Max (1970) Lessing und Aristotles. Untersuchungen über die Theorie der Tragödie, Frankfurt am Main.

Lacoue-Labarthe, Philippe (2003) 'Oedipus as figure', Radical Philosophy II8 (2003), 7-I7.

Lambropoulos, Vassilis (2006) The tragic idea, London.

Lessing, Gotthold Ephraim (1962) Hamburg dramaturgy, trans. Helen Zimmern, New York.

Loraux, Nicole (1973) 'L'interférence tragique', Critique 3I7 (I973), 908-25.

(2002) The mourning voice: an essay on Greek tragedy, Ithaca, NY.

Lurie, Michael (2012) 'Facing up to tragedy: towards an intellectual history of Sophocles in Europe from

Camerarius to Nietzsche', in Kirk Ormand (ed.) A companion to Sophocles, Oxford, 440-6I.

Martindale, Charles (1993) Redeeming the text: Latin poetry and the hermeneutics of reception, Cambridge.

Marx, Karl (I869) Der achtzehnte Brumaire des Louis Bonaparte, Hamburg.

(1975) Early writings, intro. Lucio Colletti, trans. G. Benson and R. Livingstone, Harmondsworth.

(2002) 'The eighteenth Brumaire of Louis Bonaparte', trans. Terrell Carver, in Mark Cowling and James Martin (eds.) Marx's 'Eighteenth Brumaire': (post)modern interpretations, London, I9-II2.

Marx, Karl and Engels, Friedrich (1976) Werke, vol. I, Berlin.

Mazlish, Bruce (1972) 'The tragic farce of Marx, Hegel and Engels: a note', History and Theory II (3), $335-7$.

Most, Glenn W. (2000) 'Generating genres: the idea of the tragic', in Mary Depew and Dirk Obbink (eds.) Matrices of genre: authors, canons, and society, Cambridge, $15-36$. 
Nietzsche, Friedrich (1999) The birth of tragedy and other writings, ed. Raymond Geuss and Ronald Spiers, trans. Ronald Spiers, Cambridge.

Paolucci, Anne and Paolucci, Henry (eds.) (1962) Hegel on tragedy, New York, Evanston, San Francisco and London.

Prawer, S. S. (1976) Karl Marx and world literature, Oxford.

Puchner, Martin (20I0) The drama of ideas: Platonic provocations in theater and philosophy, Oxford.

Ramazani, J. (I99I) 'Freud and tragic affect: the pleasures of dramatic pain', Psychoanalytic Review 78 (I99I), 77-IOI.

Rokem, Freddie (2009) Philosophers and thespians: thinking performance, Stanford.

Rudnytsky, Peter (I987) Freud and Oedipus, New York.

Schmidt, Dennis (200I) On Greeks and other Germans: tragedy and ethical life, Bloomington, Ind.

Schwab, Gail (2010) 'Mothers, sisters, and daughters: Luce Irigaray and the female genealogical line in the stories of the Greeks', in Elena Tzelepis and Athena Athanasiou (eds.) Rewriting difference: Luce Irigaray and 'the Greeks', Albany, NY.

Seidensticker, Bernd (1996) 'Peripeteia and tragic dialectic in Euripidean tragedy', in Silk (1996), 377-96. Silk, Michael (ed.) (I996) Tragedy and the tragic: Greek theatre and beyond, Oxford.

Silk, Michael and Stern J. P. (I98I) Nietzsche on tragedy, Cambridge.

Steiner, George (1984) Antigones: the Antigone myth in Western literature, art and thought, Oxford.

Szondi, Peter (2002) An essay on the tragic, trans. by Paul Fleming, Stanford.

Vernant, Jean-Pierre and Vidal-Naquet, Pierre (1988) Myth and tragedy in ancient Greece, trans. Janet Lloyd, New York.

Wilmer, S. E. and Zukauskaite, Audrone (eds.) (2010) Interrogating Antigone in postmodern philosophy and criticism, Oxford.

Wininger, Kathleen (I997) Nietzsche's reclamation of philosophy, Amsterdam.

Winkler, J. J. and Zeitlin, Froma (eds.) (I990) Nothing to do with Dionysus?: Athenian drama in its social context, Princeton, NJ.

White, Hayden (I973) Metahistory: the historical imagination in nineteenth-century Europe, Baltimore.

Žižek, Slavoj (2009) First as tragedy, then as farce, London. 